\title{
GM-CSF and GM-CSF $\beta$ c receptor in adult patients with pulmonary alveolar proteinosis
}

\author{
B. Bewig*, X-D. Wang*, D. Kirsten ${ }^{\#}$, K. Dalhoff ${ }^{+}$, H. Schäfer*
}

\begin{abstract}
GM-CSF and GM-CSF $\beta$ c receptor in adult patients with pulmonary alveolar proteinosis. B. Bewig, X-D. Wang, D. Kirsten, K. Dalhoff, H. Schäfer. (C)ERS Journals Ltd 2000.

ABSTRACT: Pulmonary alveolar proteinosis (PAP) is a rare disorder of unknown origin characterized by alveolar fillings with periodic acid-Schiff (PAS)-positive material mainly consisting of phospholipids. Mice defective in the granulocytemacrophage colony-stimulating factor (GM-CSF) gene or the GM-CSF/interleukin (IL)-3/IL-5-receptor common $\beta$ chain $(\beta c)$ demonstrate a pathology resembling PAP. $A$ recent study revealed defects in the $\beta c$ chain of the GM-CSF receptor in four out of eight paediatric patients. This study investigates the role of the GM-CSF coding region and components of the GM-CSF receptor in adult patients.

Four adult patients with proven PAP were analysed for GM-CSF and GM-CSF- $\beta \mathrm{c}$ receptor in regard to protein level, messenger ribonucleic acid (mRNA) expression and sequence composition.

None of the adult patients displayed the mutation at position 1,835 of the $\beta c$ receptor previously described in paediatric patients. Expression of the $\beta \mathrm{c}$ receptor was found to be normal on the surface of peripheral blood cells. In three out of four patients GM-CSF release from blood cells failed to respond adequately to lipopolysaccharide (LPS). In one of these patients a heterozygous mutation was found in the GM-CSF complementary deoxyribonucleic acid (cDNA) from thymine (T) to cytosine $(C)$ at position 382 of the published sequence putatively causing a change in the protein from isoleucine to threonine at position 117.

This study indicates that the mutation of the $\beta$ chain receptors found in some of the paediatric patients suffering from pulmonary alveolar proteinosis is not a common problem in adult patients.
\end{abstract}

Eur Respir J 2000; 15: 350-357.

\begin{abstract}
*Dept of Internal Medicine, ChristianAlbrechts University, Kiel, Germany. ${ }^{\#}$ Hospital Großhansdorf, Großhansdorf, Germany. ${ }^{+}$Dept of Internal Medicine, Medical University, Lübeck, Germany.
\end{abstract}

Correspondence: B. Bewig

Dept of Internal Medicine

Schittenhelmstr. 12

24105 Kiel

Germany

Fax: 494315971302

Keywords: Granulocyte-macrophage colony-stimulating factor

pulmonary alveolar proteinosis

Received: July 21999

Accepted after revision September 301999
Pulmonary alveolar proteinosis (PAP) in adult patients is a rare disorder of unknown origin. The disease is characterized by the accumulation of periodic acid-Schiff (PAS)positive material in the alveoli of the lung. This material consists of phospholipids and proteins derived from surfactant proteins $[1,2]$. PAP has been observed "idiopathic" or in association with haematological malignancies, infections or exposure to inhaled chemical. The diagnosis of PAP is based on bronchoalveolar lavage findings or histology [3].

Abnormal composition of alveolar proteins in PAP suggests involvement of surfactant production or surfactant metabolism in the development of the disease. Surfactant, a mixture of phospholipids and associated surfactant proteins (SP;-A, SP-B, SP-C, SP-D), is synthesized and secreted by type II pneumocytes. Clearance of surfactant is achieved by recycling and degradation in alveolar macrophages and in type II pneumocytes $[4,5]$. Congenital PAP has been attributed to diminished levels of surfactant protein B caused by a frameshift mutation (121ins2) resulting in functional and quantitative disturbance of SP-A and $-\mathrm{C}[6,7]$. In adults, these mutations in the surfactant coding sequences have not been found. However, abnormal macrophage function was identified in patients with PAP in 1979 suggesting PAP in adults is caused by defective clearance of surfactant in alveolar macrophages rather than by abnormal production [8-10]. Recent studies suggest granulocyte-macrophage colony-stimulating factor (GM-CSF) and GM-CSF-receptor to be involved in the metabolism of SP and lipids [11-14]. Mice defective in the GM-CSF gene or the GM-CSF/interleukin (IL)-3/ IL-5-receptor common $\beta$ chain $(\beta \mathrm{c})$ demonstrate a pathology resembling PAP with increased amounts of surfactant in the alveoli and in the macrophages. Similar to adult humans, no accumulation of surfactant or its precursor was detected in the type II pneumocytes of the mice. These observations indicate a role of GM-CSF or its receptor in processing surfactant within alveolar macrophages.

In humans defects in the GM-CSF receptor have been described in four out of eight paediatric patients [15]. However, no abnormalities in the GM-CSF gene have been described yet, although a report suggests missing protein in the presence of normal amounts of GM-CSF messenger ribonucleic acid (mRNA) [16].

The authors analysed GM-CSF and GM-CSF receptor for protein levels, mRNA expression and sequence composition in four adult patients with PAP. 


\section{Materials and methods}

\section{Patients}

Four patients were available for analysis (PAPa, PAPb, PAPc, PAPd). All patients had clinical manifestations of the disease (table 1). In one patient histology revealed pulmonary alveolar proteinosis associated with interstitial inflammation (PAPc). Up to seven persons without evidence of PAP were investigated as control subjects. All patients gave their written consent to participate in this study. The study was performed in accordance to the Helsinki declaration of 1964.

\section{Isolation of mononuclear cells from peripheral blood}

Venous blood was taken from patients in ethylene diamine tetra-acetic acid (EDTA)-anticoagulated tubes and diluted with phosphate-buffered saline (PBS). Peripheral blood mononuclear cells (PBMCs) were separated by density gradient centrifugation over Ficoll-Hypaque separating solution (density 1.077 ) at $500 \times g$ at $20^{\circ} \mathrm{C}$ for $20 \mathrm{~min}$. PBMCs were recovered from the interphase between plasma and Ficoll-Hypaque by needle aspiration and washed twice in PBS.

\section{Harvesting bronchoalveolar lavage cells}

Bronchoalveolar lavage (BAL) or whole lung lavage were performed therapeutically for removal of phospholipids and proteins from the alveolar spaces using prewarmed sodium chloride $(0.9 \%)$ or standard Ringer solution. Lavage fluid was gathered and cell pellets were collected by centrifugation at $300 \times g$ for $5 \mathrm{~min}$. Cells were resuspended in PBS or Dulbecco's minimum essential medium (MEM) and grown on culture dishes. Alveolar macrophages were selected by washing due to their increased adherence to surfaces compared to leukocytes.

Table 1. - Clinical details of pulmonary alveolar proteinosis (PAP)

\begin{tabular}{|c|c|c|c|c|}
\hline & PAPc & $\mathrm{PAPb}$ & PAPc & PAPd \\
\hline Sex & M & M & $\mathrm{F}$ & M \\
\hline Age yrs & 59 & 35 & 22 & 45 \\
\hline Symptoms/signs & $\mathrm{D}, \mathrm{C}, \mathrm{Cr}$ & $\mathrm{D}, \mathrm{C}$ & $\mathrm{D}, \mathrm{C}$ & $\mathrm{D}, \mathrm{C}, \mathrm{CP}$ \\
\hline Chest radiograph & BI & BI & BI & BI \\
\hline Lung function & PR, DDC & PR, DDC & PR, DDC & PR, DDC \\
\hline $\begin{array}{l}\text { Background } \\
\text { disease }\end{array}$ & None & None & None & None \\
\hline $\begin{array}{l}\text { Diagnostic } \\
\text { procedure }\end{array}$ & $\begin{array}{c}\text { BAL + } \\
\text { TLB }\end{array}$ & $\begin{array}{c}\text { BAL + } \\
\text { TLB }\end{array}$ & TLB & $\begin{array}{c}\text { BAL + } \\
\text { TLB }\end{array}$ \\
\hline \multicolumn{5}{|c|}{ BAL cell differential } \\
\hline Macrophage \% & 71 & 78 & 73 & 61 \\
\hline Lymphocyte \% & 21 & 14 & 6 & 34 \\
\hline Neutrophil \% & 7 & 8 & 19 & 4 \\
\hline Eosinophil \% & 1 & 0 & 2 & 1 \\
\hline \multicolumn{5}{|l|}{ Blood gas analyses } \\
\hline$P \mathrm{a}, \mathrm{O}_{2} \mathrm{mmHg}$ & 67 & 72 & 84 & 72 \\
\hline $\mathrm{Pa}_{\mathrm{a}, \mathrm{CO}_{2} \mathrm{mmHg}}$ & 30 & 37 & 34 & 29 \\
\hline
\end{tabular}

M: male; F: female; D: dyspnoea; C: cough; Cr: crackles; CP: chest pain; BI: bilateral infiltrates; PR: pulmonary restriction; DDC: decreased diffusion capacity; BAL: bronchoalveolar lavage; TLB: transbronchial lung biopsy; $\mathrm{Pa}_{\mathrm{a}} \mathrm{O}_{2}$ : arterial oxygen tension; $\mathrm{Pa}, \mathrm{CO}_{2}$ : arterial carbon dioxide tension.

\section{Cell culture and stimulation}

Isolated PBMCs and lavage cells were resuspended in $37^{\circ} \mathrm{C}$ prewarmed Dulbecco's MEM (Life Technologies $\mathrm{GmbH}$, Eggenstein, Germany) supplemented with 10\% foetal calf serum (FCS; Life Technologies $\mathrm{GmbH}$ ) and 100 $\mathrm{U} \cdot \mathrm{mL}^{-1}$ penicillin (Life Technologies $\mathrm{GmbH}$ ) and 100 $\mu \mathrm{g} \cdot \mathrm{mL}^{-1}$ streptomycin (Life Technologies $\mathrm{GmbH}$ ) to a concentration of $1 \times 10^{6}$ cells $\cdot \mathrm{mL}^{-1}$. For reverse transcriptasepolymerase chain reaction (RT-PCR) analysis of GM-CSF mRNA cells were stimulated with lipopolysaccharide (LPS; Sigma, St. Louis, MO, USA) at a concentration of 2 $\mu \mathrm{g} \cdot \mathrm{mL}^{-1}$ in a humidified chamber at $37^{\circ} \mathrm{C}$ for $0,4,12$ or 24 h. For protein analysis cells were incubated with LPS for $24 \mathrm{~h}$. For RT-PCR of the $\beta \mathrm{c}$ receptor mRNA, cells were processed without cultivation and without stimulation.

\section{Protein analysis}

GM-CSF protein quantification. GM-CSF levels were determined in plasma, supernatants of cultured PBMCs and cultured BAL cells using an enzyme-linked immunosorbent assay (GM-CSF ELISA; Immunotech, Marseille, France) following the instructions of the manufacturer. Briefly, microtitre plates coated with mouse anti-human GM-CSF monoclonal antibody were incubated with $50 \mu \mathrm{L}$ of serum, supernatant or control at room temperature for 2 h. After washing a biotinylated second antibody against mouse antihuman GM-CSF antibody was added together with streptavidin-conjugated peroxidase. After incubation at room temperature for $30 \mathrm{~min}$ and washing, a chromogenic substrate was added. Extinction was taken at 450 nm using a BioRad EIA reader (Bio-Rad Laboratories $\mathrm{GmbH}$, München, Germany). Concentration of GM-CSF was determined using a standard curve. The sensitivity of the assay was $5 \mathrm{pg} \cdot \mathrm{mL}^{-1}$.

Flow cytometry analysis of GM-CSF/IL-3/IL-5 receptor common $\beta$ chain expression. GM-CSF/IL-3/IL-5 receptor common $\beta c$ expression was analysed by flow cytometry as previously described [15]. Two hundred microlitres of whole blood was incubated with a monoclonal mouse anti-human GM-CSF/IL-3/IL-5 receptor $\beta c$ antibody (Genzyme, Cambridge, MA, USA) at room temperature for $30 \mathrm{~min}$. Red blood cells were lysed by fluorescenceactivated cell sorter (FACS) lysing solution (Becton Dickinson, Heidelberg, Germany). Remaining leukocytes were collected by centrifugation and washed with PBS (GibcoBRL). Staining was accomplished using $4 \mu \mathrm{L}$ of fluorescein isothiocyanate (FITC)-conjugated second antibody (goat anti-mouse immunoglobulin (Ig)-FITC; Becton Dickinson). Fluorescence was detected by FACScan flow cytometer (Becton Dickinson). At least 10,000 cells were analysed in each sample. Results from fluorescence intensity analysis represent percentage of cells expressing $\beta c$ receptor.

Ribonucleic acid extraction. BAL cells or PBMCs were used for RNA extraction applying an RNA isolation kit (High pure RNA isolation kit; Boehringer Mannheim, Mannheim, Germany). Briefly, $1-4 \times 10^{6}$ unstimulated or LPS-stimulated cells in a volume of $200 \mu \mathrm{L}$ were denatured in $400 \mu \mathrm{L}$ lysis-buffer and added to a fibre fleece in a filter tube. After centrifugation deoxyribonuclease (DNase) I 
(1,800 U) was applied. RNA was eluted after two washing steps by adding water to the filter tube and another centrifugation. Concentration of RNA was determined spectrophotometrically at $260 \mathrm{~nm}$. Samples were stored in liquid nitrogen for further processing.

First-stranded complementary deoxyribonucleic acid synthesis. Total RNA was used for first-stranded complementary deoxyribonucleic acid (cDNA) in a reverse transcription system (Reverse transcription system; Promega, Madison, WI, USA) following the instructions of the manufacturer. Briefly, a $20 \mu \mathrm{L}$ reaction mixture containing $1 \mu \mathrm{g}$ total RNA, $0.5 \mu \mathrm{g}$ oligo(deoxythymidine (dT)) 15 primer, $1 \mathrm{mM}$ each deoxynucleotide (dNTP), $15 \mathrm{U}$ avian myeloblastoses virus (AMV) reverse transcriptase, $20 \mathrm{U}$ ribonuclease inhibitor (rRNasin), $5 \mathrm{mM} \mathrm{MgCl}_{2}$ and $1 \times$ reverse transcription buffer $(10 \mathrm{mM}$ Tris- $\mathrm{HCl}, 50 \mathrm{mM} \mathrm{KCl}$ and $0.1 \%$ Triton $\mathrm{X}-100$ ) was incubated at $42^{\circ} \mathrm{C}$ for $15 \mathrm{~min}$, followed by an incubation at $99^{\circ} \mathrm{C}$ for $5 \mathrm{~min}$. The reaction was stopped by 5 min incubation at $5^{\circ} \mathrm{C}$.

Polymerase chain reaction. First stranded cDNAs were amplified in a thermocycler (Perkin Elmer Biosystems, Foster City, CA, USA) by PCR as described previously. A reaction volume of $40 \mu \mathrm{L}$ containing $1 \times$ PCR buffer $(10$ $\mathrm{mM}$ Tris $\mathrm{HCl}, 0.1 \%$ Triton $\mathrm{X}-100$, and $1.5 \mathrm{mM} \mathrm{MgCl}_{2}, \mathrm{pH}$ 9.0), $2 \mu \mathrm{L}$ reversed transcripted first-stranded cDNA (100 ng RNA), $200 \mu \mathrm{M}$ each dNTP, $250 \mathrm{nM}$ sense and antisense primer each, and $0.5 \mathrm{U}$ Taq DNA polymerase was used for PCR with the temperature protocol of $95^{\circ} \mathrm{C}$ for $5 \mathrm{~min}$ followed by 30 cycles of denaturation at $95^{\circ} \mathrm{C}$ for $1 \mathrm{~min}$, annealing at $56^{\circ} \mathrm{C}$ (GM-CSF or human $\beta$-actin primer) or $60^{\circ} \mathrm{C}$ (GM-CSF $\beta \mathrm{c}$ receptor primer) for $1 \mathrm{~min}$ and elongation at $72^{\circ} \mathrm{C}$ for $1 \mathrm{~min}$. Final extension was at $72^{\circ} \mathrm{C}$ for 10 min at the end of 30 cycles.

Primer. GM-CSF cDNA (536 base pair (bp) amplification product): sense primer: 5'-GCT AAA GTT CTC TGG AGG ATG-3' (position 15-35 of the published cDNA); antisense primer: 5'-CTC CAA GAT GAC CAT CCT GAG-3' (position 550-530 of the published cDNA).

$\beta c$ receptor cDNA (amplification product $500 \mathrm{bp}$ ): sense primer: 5'-GAG GTG TCA CCT CTC ACC AT-3' (position 1,625-1,644 of the published cDNA); antisense primer: 5'-GAG CTC ATG GGT ATA GCC AC-3' (position 2,124-2,105 of the published cDNA).

Human $\beta$ actin primer (amplification product $785 \mathrm{bp}$ ): sense primer: 5'-GAC GAG GCC CAG AGC AAG-3' (position 207-224 of the published cDNA); antisense primer: 5'-ATC TCC TTC TGC ATC CTG TC-3' (position 991-972 of the published cDNA).

Gel electrophoresis. Amplification products were analysed by electrophoresis on a $1.2 \%$ agarose gel in $1 \times$ TAE buffer (40 mM Tris acetate, $2 \mathrm{mM}$ EDTA). Visualization was achieved after ethidium bromide staining by ultraviolet illumination. Results were documented taking photographs with a Polaroid camera system (Polaroid camera systems, Cambridge, MA, USA).

Sequencing of complementary deoxyribonucleic acid. The GM-CSF cDNA and the $\beta c$ receptor cDNA were analysed by sequencing. GM-CSF cDNA was amplified as described above. Four overlapping fragments $(F 1, F 2, F 3, F 4)$ of the $\beta c$ receptor cDNA were amplified separately. The authors used the primers: F1 sense: 5'-TGA CCA GGG AGA TGG
TGC TG-3' (position 18-37); F1 antisense: 5'-GTT TCT CTG CCC TCC TTG GCT-3' (position 1,019-998); F2 sense: 5'-CCC ACG GCC AAT ACA TCG TC-3' (position 972-991); F2 antisense: 5'-CCA GAT GGT GGA TCA CAG AC-3' (position 1,680-1,661); F3 sense: 5'-GAG GTG TCA CCT CTC ACC AT-3' (position 1,625-1,644); F3 antisense: 5'-GAG CTC ATG GGT ATA GCC AC-3' (position 2,124-2,105); F4 sense: 5'-CAG CCC TGT GGC TAT ACC CA-3' (position 2,098-2,117); F4 antisense: 5'AAG GTC AGG CGG GAG GGA AG-3' (position 2,7842,765).

Amplified products were subcloned into pCR2.1 using the TA cloning kit following the instructions of the manufacturer (Invitrogen, San Diego, CA, USA) Briefly, $10 \mu \mathrm{L}$ reaction mixture containing ligation buffer $(6 \mathrm{mM}$ Tris$\mathrm{HCl}, 6 \mathrm{mM} \mathrm{MgCl}_{2}, 5 \mathrm{mM} \mathrm{NaCl}, 7 \mathrm{mM} \beta$-mercaptoethanol, $0.1 \mathrm{mM}$ adenosine triphosphate (ATP), $2 \mathrm{mM}$ dithiothreitol, $1 \mathrm{mM}$ spermidine, $0.1 \mathrm{mg} \cdot \mathrm{mL}^{-1}$ bovine serum albumin (BSA), $\mathrm{pH} 7.5), 1 \mu \mathrm{L}$ PCR product, $2 \mu \mathrm{L}$ pCR2.1 vector $\left(25 \mathrm{ng} \cdot \mu \mathrm{L}^{-1}\right), 1 \mu \mathrm{L}$ T4 DNA ligase and distilled water was incubated at $14^{\circ} \mathrm{C}$ overnight.

pCR2.1 vector containing the amplified PCR product was used for transformation of Escherichia coli competent cells (INV $\alpha F^{\prime}$ cells; Invitrogen). Briefly, $2 \mu \mathrm{L}$ of $0.5 \mathrm{mM} \beta$ mercaptoethanol and $2 \mu \mathrm{L}$ of the ligation reaction were transferred to a vial of competent cells. After incubation on ice for $30 \mathrm{~min}$, cells were exposed to $42^{\circ} \mathrm{C}$ for $30 \mathrm{~min}$ and then cooled down on ice again. Two hundred and fifty microlitres of $37^{\circ} \mathrm{C}$ prewarmed SOC medium (2\% tryptone, $0.5 \%$ yeast extract, $10 \mathrm{mM} \mathrm{NaCl}, \mathrm{KCl}, 10 \mathrm{mM}$ $\mathrm{MgCl}_{2}, 20 \mathrm{mM}$ glucose $\mathrm{pH}$ 7.0) were added to the cells followed by an incubation at $37^{\circ} \mathrm{C}$ for $1 \mathrm{~h}$. One hundred and fifty microlitres cell culture from each transformation were spread on a Luria-Bertani (LB: $1 \%$ tryptone, $0.5 \%$ yeast extract, $1 \% \mathrm{NaCl}, \mathrm{pH} 7.0,50 \mu \mathrm{g} \cdot \mathrm{mL}^{-1}$ ampicillin and $40 \mu \mathrm{L} \mathrm{X-Gal)} \mathrm{agar} \mathrm{plate.} \mathrm{The} \mathrm{plate} \mathrm{was} \mathrm{incubated} \mathrm{at} 37^{\circ} \mathrm{C}$ overnight and at $4{ }^{\circ} \mathrm{C}$ for $2 \mathrm{~h}$. Five to 10 white colonies were picked from each plate and transferred to $5 \mathrm{~mL}$ LB medium containing ampicillin $\left(50 \mu \mathrm{g} \cdot \mathrm{mL}^{-1}\right)$ for overnight growth at $37^{\circ} \mathrm{C}$.

Cultured E. coli were used for DNA extraction applying the QIAprep miniprep protocol (Quiagen, Hilden, Germany). Briefly, bacterial cells were pelleted by centrifugation at $1,200 \times g$ for $5 \mathrm{~min}$, resuspended in $250 \mu \mathrm{L}$ buffer, and lysed with $250 \mu \mathrm{L}$ lysis buffer before a final denaturation buffer was added. After centrifugation at 10,000 $\times g$ for $10 \mathrm{~min}$ the supernatant was applied to a spin column capturing the DNA during a further centrifugation step. Two more washings were performed before finally DNA was eluted in $50 \mu \mathrm{L}$ of buffer $(10 \mathrm{mM}$ Tris $\mathrm{HCl}, \mathrm{pH} 8.5)$. DNA concentration was determined spectrophotometrically.

Final sequencing was performed by the Sanger dideoxy-mediated chain termination method utilizing the SequiTherm EXCEL II Long Read DNA sequencing kit (Epicentre Technologies, Madison, WI, USA). The procedure followed the modified instructions of the manufacturer. Instead of radiolabelled probes fluorophore labelled sequencing primers were used. The primers (M13 forward primer: 5'-AGG GTT TTC CCA GTC ACG ACG TT-3' and M13 reverse primer: 5'-GAG CGG ATA ACA ATT TCA CAC AGG-3'; MWG Biotech, Ebersberg, Germany) were labelled with IRD800 dye at the 5 'ends.

Gel electrophoresis and detection of fluorescence was accomplished by DNA sequencer (DNA sequencer 4,000 
L; LI-COR Lincoln, NE, USA). Sequencing gel solution (SequaGel XR; National Diagnostics, Atlanta, GA, USA) was mixed with $7.5 \mathrm{~mL}$ SequaGel complete buffer and 350 $\mu \mathrm{L} 10 \%$ ammonium persulphate, then poured into the chamber and allowed to polymerize for $2 \mathrm{~h}$. Gel was run in $1 \times$ TBE (134 mM Tris base, $45 \mathrm{mM}$ boric acid, $2.5 \mathrm{mM}$ EDTA) at $1,500 \mathrm{~V}, 50 \mathrm{~W}$ and $37 \mathrm{~mA}$ for $30 \mathrm{~min}$ before the samples were loaded to the gel $(1 \mu \mathrm{L}$ each). Final run was performed for $12-18 \mathrm{~h}$. DNA sequence was automatically analysed by the Base ImageIR software (MWG Biotech, Ebersberg, Germany) and controlled manually.

\section{Results}

GM-CSF protein in plasma and supernatant of cultured peripheral blood mononuclear cells

Concentration of GM-CSF in plasma was determined by enzyme linked immunosorbent assay (ELISA)-technique (sensitivity $5 \mathrm{pg} \cdot \mathrm{mL}^{-1}$ ). In one out of seven control subjects GM-CSF was detected at a concentration of 9 $\mathrm{pg} \cdot \mathrm{mL}^{-1}$, all other control subjects and all four patients with alveolar proteinosis had undetectable levels of GMCSF in plasma (data not shown).

PBMCs were separated and grown in cell culture in the presence or absence of LPS. The supernatant was collected for GM-CSF determination. Only samples from two control subjects secreted GM-CSF at a measurable amount (8.8 and $19.2 \mathrm{pg} \cdot \mathrm{mL}^{-1}$ supernatant). All other samples from five controls and from all patients with PAP were negative for GM-CSF without stimulation (table 2). After stimulation of separated PBMCs with LPS for $24 \mathrm{~h}$ GM-CSF was detectable in all control subjects. The concentration was between 35 and $165 \mathrm{pg}$ GM-CSF.mL ${ }^{-1}$ cell supernatant. In one of the patients suffering from PAP (PAPc) GMCSF was found within the same range of concentration $\left(115 \mathrm{pg} \cdot \mathrm{mL}^{-1}\right)$. However, two other patients with PAP produced only low level GM-CSF (11 and $5.2 \mathrm{pg} \cdot \mathrm{mL}^{-1}$ respectively) and in the third patient no GM-CSF was detectable (table 2).

\section{GM-CSF release from bronchoalveolar lavage cells}

Alveolar macrophages from BAL were cultivated and grown with or without LPS for $24 \mathrm{~h}$. The supernatant was analysed for GM-CSF by the ELISA-technique. Two patients with PAP were available for this analysis. They were compared with four control lavages (table 3 ). If the cells were not stimulated with LPS control subjects had no (three control subjects) or low level $\left(8 \mathrm{pg} \cdot \mathrm{mL}^{-1}\right) \mathrm{GM}-$ CSF production (one control subject). Both patients had slightly higher GM-CSF levels without stimulation. Upon challenge with LPS samples from all control subjects and one of the PAP patients (PAPc) had significant GM-CSF concentrations $\left(675-2,100 \mathrm{pg} \cdot \mathrm{mL}^{-1}\right)$. The other PAP patient had only minimal GM-CSF levels in the BAL cell supernatant $\left(32.5 \mathrm{pg} \cdot \mathrm{mL}^{-1}\right)$.

GM-CSF messenger ribonucleic acid expression in peripheral blood mononuclear cell

PBMCs were isolated and incubated in the presence or absence of LPS. After RNA extraction from PBMCs cDNA was transcribed by reverse transcriptase and amp-
Table 2. - Granulocyte - macrophage colony - stimulating factor (GM-CSF) release from peripheral blood mononuclear cells in patients with pulmonary alveolar proteinosis (PAP) and control subjects

\begin{tabular}{|c|c|c|}
\hline \multirow[t]{2}{*}{ Subjects } & \multicolumn{2}{|c|}{ GM-CSF pg.mL ${ }^{-1}$} \\
\hline & LPS- & $\begin{array}{c}\text { LPS+ } \\
2 \mu \mathrm{g} \cdot \mathrm{mL}^{-1}\end{array}$ \\
\hline PAPa & $<5$ & $<5$ \\
\hline PAPb & $<5$ & 5 \\
\hline PAPc & $<5$ & 115 \\
\hline PAPd & $<5$ & 11 \\
\hline Control 1 & 9 & 162 \\
\hline Control 2 & $<5$ & 58 \\
\hline Control 3 & $<5$ & 165 \\
\hline Control 4 & $<5$ & 95 \\
\hline Control 5 & 19 & 138 \\
\hline Control 6 & $<5$ & 55 \\
\hline Control 7 & $<5$ & 35 \\
\hline
\end{tabular}

LPS: lipopolysaccharide.

lified by PCR. The PCR product was visualized by ethidium bromide staining after gel electrophoresis. A representative gel is shown in figure 1.

In none of the control subjects and none of the patients with PAP were any GM-CSF cDNA PCR products detectable directly after isolation. Weak bands were detectable after 4-12 h of incubation (no stimulation with LPS) with a decrease after further incubation. Strongest bands were obtained after $4 \mathrm{~h}$ of incubation in the presence of LPS indicating highest amounts of GM-CSF cDNA. The time course of appearance and the strength of bands was not different between control subjects and patients with PAP.

GM-CSF messenger ribonucleic acid expression in alveolar macrophages

GM-CSF was determined in supernatants of cultured alveolar macrophages in the presence or absence of LPS according to the methods applied for PBMCs (fig. 2). No GM-CSF cDNA was detectable by PCR in unstimulated cells (four control subjects and two patients with PAP). After stimulation with LPS for $4 \mathrm{~h}$ strong bands representing presence of GM-CSF cDNA were found in all samples.

Table 3. - Granulocyte - macrophage colony - stimulating factor (GM-CSF) release from bronchoalveolar lavage cells in patients with pulmonary alveolar proteinosis (PAP) and control subjects

\begin{tabular}{lcc}
\hline Subjects & \multicolumn{2}{c}{ GM-CSF pg $\cdot \mathrm{mL}^{-1}$} \\
\cline { 2 - 3 } & LPS- & $\begin{array}{c}\text { LPS+ } \\
2 \mu \mathrm{g} \cdot \mathrm{mL}^{-1}\end{array}$ \\
\hline PAPc & 27 & 1650 \\
PAPd & 19 & 33 \\
Control 1 & $<5$ & 2100 \\
Control 2 & 8 & 775 \\
Control 3 & $<5$ & 2050 \\
Control 4 & $<5$ & 675 \\
\hline
\end{tabular}

LPS: lipopolysaccharide. 
a) $\mathrm{M} 1234567$

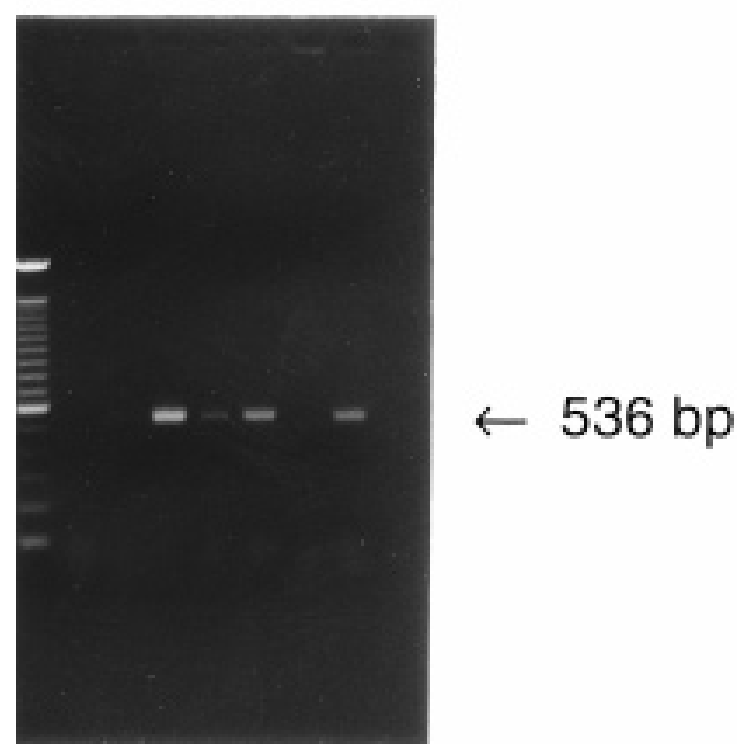

b) $\mathrm{M} 1234567$

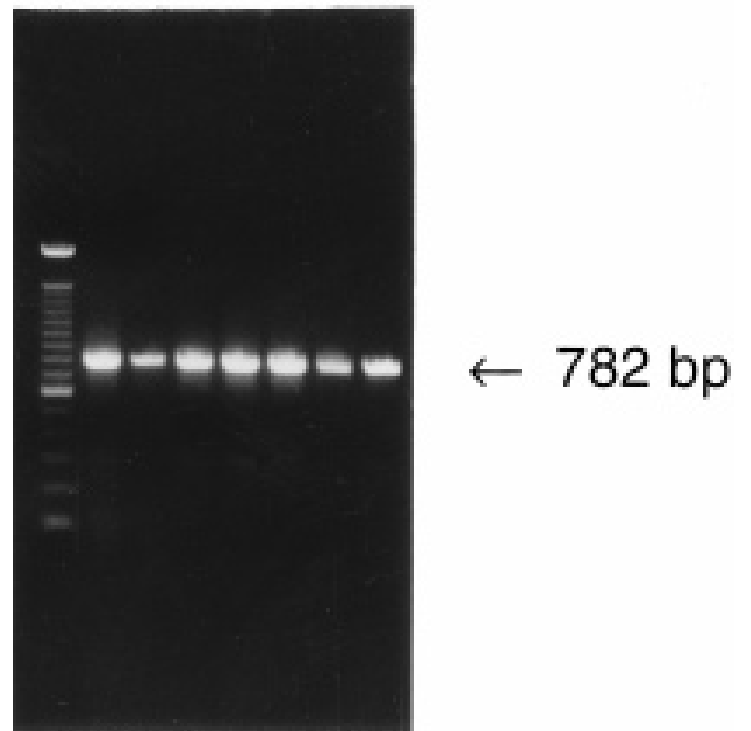

Fig. 1. - Gel electrophoresis of polymerase chain reaction (PCR) amplification products (granulocyte-macrophage colony-stimulating factor (GM-CSE) or human $\beta$ actin) from complementary deoxyribonucleic acid (cDNA) of a patient with pulmonary alveolar proteinosis (PAP) Ribonucleic acid (RNA) was isolated from peripheral blood mononuclear cells (PBMCs) grown in the absence or presence of lipopolysaccharide (LPS) $\left(2 \mu \mathrm{g} \cdot \mathrm{mL}^{-1}\right)$. cDNA was obtained by reverse transcriptase. a) GM-CSF amplification products from cDNA (536 base pairs (bp)). b) human $\beta$ actin amplification products from cDNA (782 bp). M: molecular weight marker; lane 1: no LPS, no incubation; lane 2: no LPS, $4 \mathrm{~h}$ of incubation; lane 3: with LPS, $4 \mathrm{~h}$ of incubation; lane 4: no LPS, 12 $\mathrm{h}$ of incubation; lane 5: with LPS, $12 \mathrm{~h}$ of incubation; lane 6: no LPS, 24 $\mathrm{h}$ of incubation; lane 7: with LPS, $24 \mathrm{~h}$ of incubation.

Sequence analysis of GM-CSF complementary deoxyribonucleic acid

All patients with PAP and two control subjects were analysed for sequence integrity of the cDNA. In one patient $(\mathrm{PAPa})$ a point mutation was found from thymine $(\mathrm{T})$ to cytosine (C) at position 382 of the published sequence (fig.

\section{M1234}

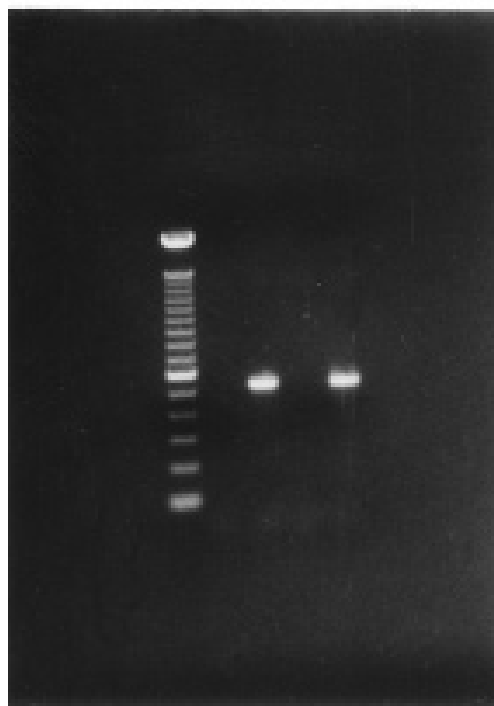

$\leftarrow 536 \mathrm{bp}$

Fig. 2. - Gel electrophoresis of polymerase chain reaction (PCR) amplification products (granulocyte-macrophage colony-stimulating factor (GM-CSF) from complementary deoxyribonucleic acid (cDNA) of a patient with pulmonary alveolar proteinosis (PAP) and a healthy control subjects. Ribonucleic acid (RNA) was isolated from bronchoalveolar lavage (BAL) cells grown in the absence or presence of lipopolysaccharide (LPS) $\left(2 \mu \mathrm{g} \cdot \mathrm{mL}^{-1}\right)$ for $4 \mathrm{~h}$. cDNA was obtained by reverse transcriptase. M: molecular weight marker; lane 1: control, no LPS; lane 2: control, with LPS; lane 3: PAP, no LPS; lane 4: PAP, with LPS.

3). This mutation putatively causes a change in the amino acid sequence at position 117 from isoleucine to threonine. Repeated analysis of completely independent clones (total of 10) from this patient revealed presence of both wildtype cDNA and the mutated form as well, suggesting a heterozygous genomic mutation. Analysis of all other control subjects and patients with PAP revealed no differences from the published sequence.

\section{GM-CSF/interleukin-3/-5 $\beta$ chain receptor protein}

GM-CSF/IL-3/IL-5 $\beta$ c receptor expression was assessed on PBMCs and polymorphonucleated cells (PMNCs) by flow cytometry using a specific monoclonal antibody directed against GM-CSF/IL-3/IL-5 $\beta$ c receptor (figs 4 and 5). All four patients with PAP and all control subjects showed normal expression of the receptor on PBMCs (56-92\% of cells positive) and PMNCs (66.1-98.2\% of cells positive).

\section{GM-CSF/interleukin-3/-5 $\beta$ chain receptor messenger} ribonucleic acid

cDNA obtained from PBMCs and BAL cells was amplified by PCR spanning the region $1,625-2,124$ bp of the GM-CSF/IL-3/IL-5 $\beta$ c receptor. The $500 \mathrm{bp}$ amplification product was analysed by gel electrophoresis and visualized after ethidium bromide staining by ultraviolet illumination (fig. 6). In all samples (control subjects and patients with PAP) similar bands of the amplification product were detectable demonstrating presence of GMCSF/IL-3/IL-5 $\beta$ c receptor cDNA. 

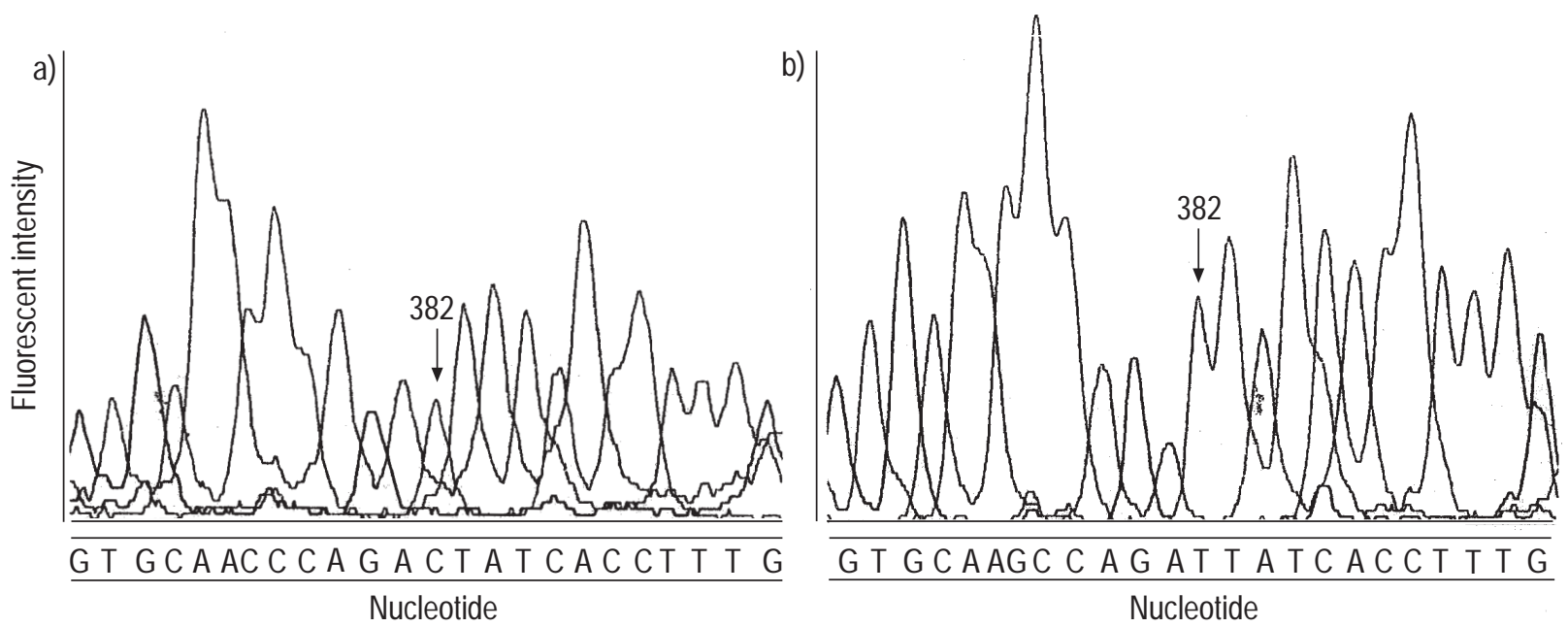

Fig. 3. - Sequence analysis of granulocyte-macrophage colony-stimulating factor (GM-CSF) complementary deoxyribonucleic acid (cDNA) from patients pulmonary alveolar proteinosis (PAP)a. a) patient; b) control (wildtype). Indicated is the mutation at position 382 of the published sequence. G: guanine; T: thymine; C: cytosine; A: adenine.

\section{Sequence analysis of GM-CSF/interleukin-3/-5 $\beta$ chain receptor complementary deoxyribonucleic acid}

GM-CSF/IL-3/IL-5 $\beta$ c receptor cDNA sequencing was performed on all patients with PAP. Two patients (PAPc and PAPd) had mutations at the position 1,972 of the published sequence. However, this change in cDNA is not associated with a change in the coding for amino acids. No abnormalities in the sequence of the GM-CSF/IL-3/IL-5 $\beta \mathrm{c}$ receptor were found in patient $\mathrm{PAPa}$ and $\mathrm{PAPb}$. Especially no mutation was found at position 1,835 .

\section{Discussion}

This study indicates that the mutation of the GM-CSF $\beta c$ receptor found in some paediatric patients suffering from PAP is not a common problem in adult patients.

Recent studies have revealed the importance of GMCSF in the regulation of surfactant balance, which may play a pathogenetic role in PAP. Transgenic mice lacking GMCSF or the common $\beta$ subunit $(\beta c)$ of the GM-CSF receptor develop a lung pathology resembling PAP [11-14]. PAP can be treated successfully, when GM-CSF production is restored in the GM-CSF knockout mouse [17-19] or when bone marrow cells expressing the $\beta c$ chain are transplanted to the GM-CSF receptor knockout mouse $[20,21]$

In paediatric patients with intact SP-B a defect in the expression of the $\beta \mathrm{c}$ receptor was found in four out of eight cases [15]. In one of these patients a mutation was detected at position 1,835 of the genomic DNA (from $\mathrm{C}$ to adenine (A)) causing a change of codon 602 from proline to threonine, a motif possibly of importance for the integrity of the $\beta c$ protein. Paediatric patients suffering from PAP related to acute myeloid leukaemia were lacking the $\beta c$ chain on their myeloic blasts [22]. After high dose chemotherapy the defective $\beta c$ clone was eliminated and patients recovered from PAP symptoms. Defects in the $\beta \mathrm{c}$
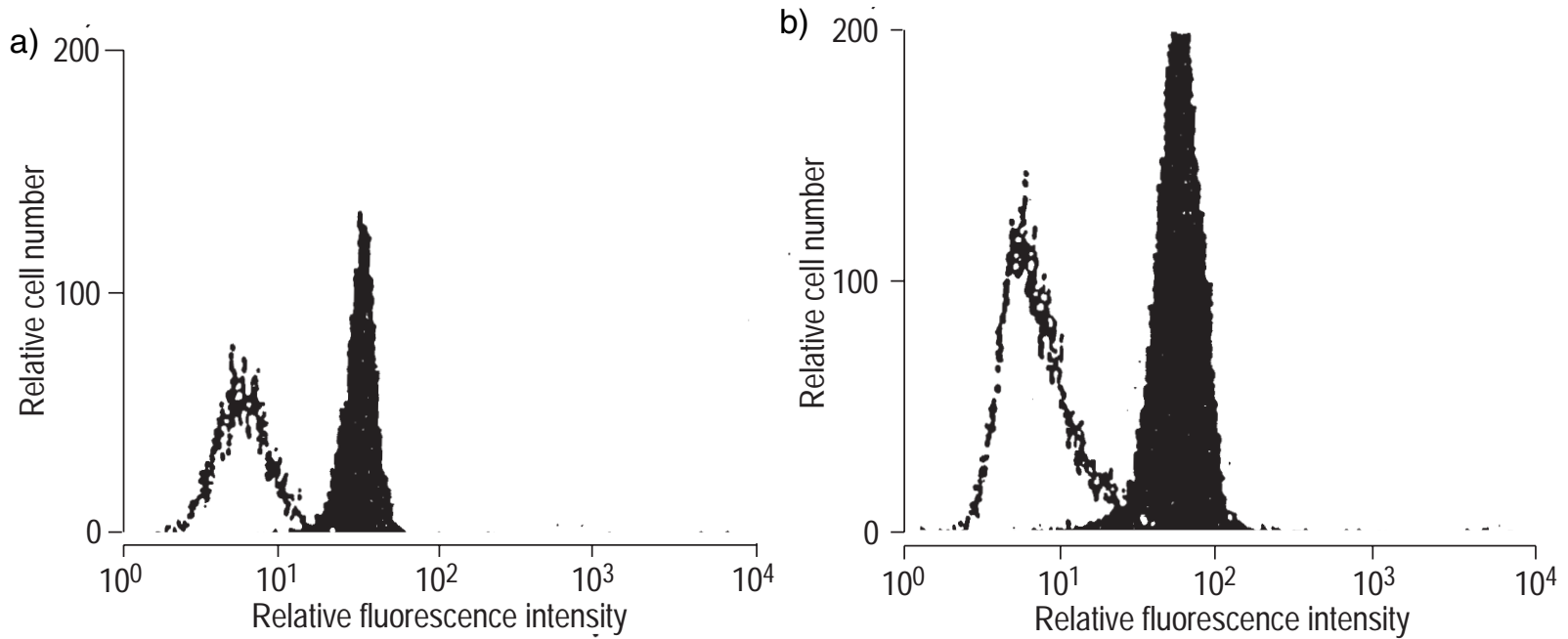

Fig. 4. - Flow cytometry analysis of granulocyte-macrophage colony-stimulating factor (GM-CSF) interleukin (IL)-3/IL-5 $\beta$ chain ( $\beta \mathrm{c}$ ) expression on polymorphnuclcated cells (PMNC). Intensity of fluorescence is shown on the $\mathrm{x}$-axis, relative cell number is represented on the y-axis. Light areas represent gated PMNs, shaded area indicate cells after binding to the GM-CSF/IL-3/IL-5 $\beta c$ receptor antibody. a) Control subject, b) patient with pulmonary alveolar proteinosis (PAP). 
a)

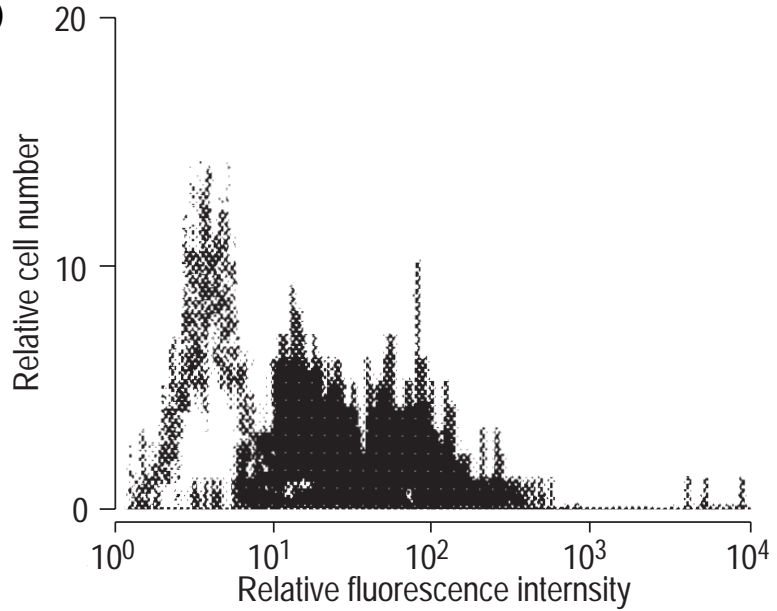

b)

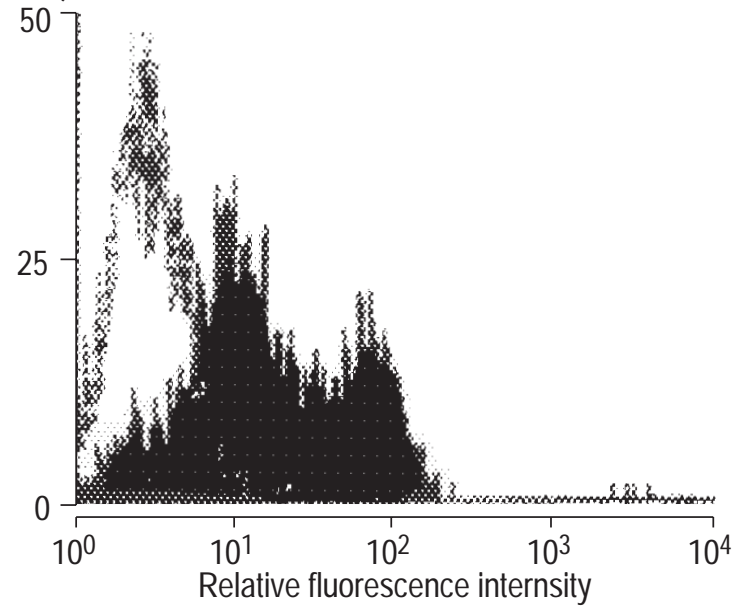

Fig. 5. - Flow cytometry analysis of granulocyte-macrophage colony-stimulating factor (GM-CSF) interleukin (IL)-3/IL-5 $\beta$ chain ( $\beta$ c) expression on peripheral blood mononuclear cells (PBMC). Intensity of fluorescence is shown on the x-axis, relative cell number is represented on the y-axis. Light areas represent gated PBMCs, shaded area indicate cells after binding to the GM-CSF/IL-3/IL-5 $\beta \mathrm{c}$ receptor antibody. a) Control subject, b) patient with pulmonary alveolar proteinosis (PAP).

chain may also be responsible for recurrence of alveolar proteinosis after lung transplantation [23].

In the current study none of the patients displayed abnormalities in the $\beta \mathrm{c}$ expression on the cell surface and no mutation was found at the previously described locus. Two patients had mutations at position 1,972 of the published $\beta c$ sequence, which was not associated with a

\section{M1234}

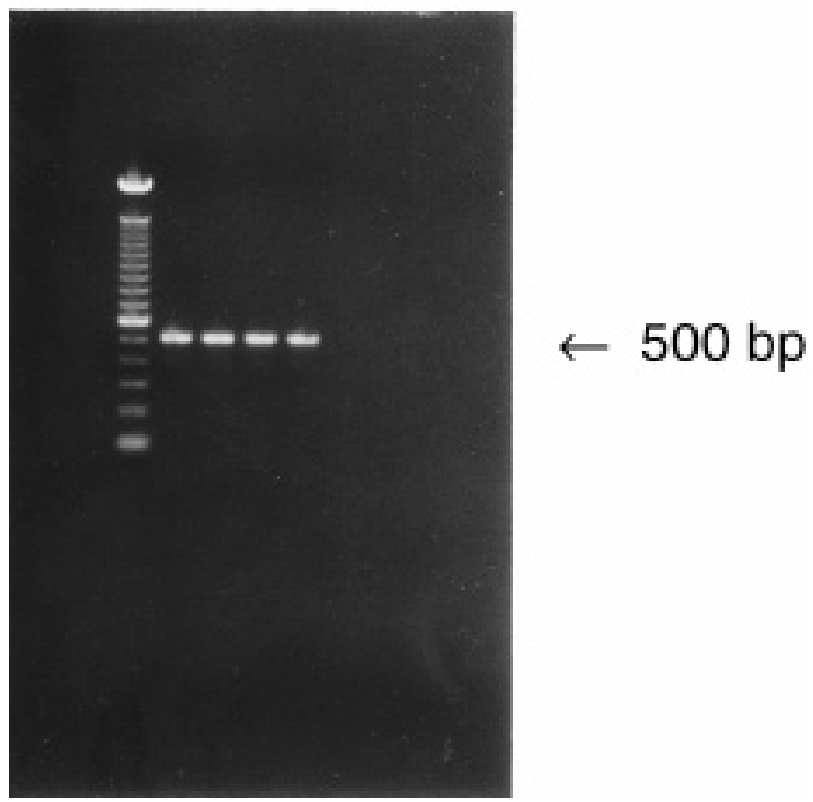

Fig. 6. - Gel electrophoresis of polymerase chain reaction (PCR) amplification products granulocyte-macrophage colony-stimulating factor ((GM-CSF) interleukin (IL)-3/IL-5 $\beta$ chain $(\beta c)$ receptor, 500 base-pairs (bp)) from complementary deoxyribonucleic acid (cDNA) of a patient with pulmonary alveolar proteinosis (PAP). Ribonucleic acid (RNA) was isolated from peripheral blood mononuclear cells (PBMCs) or bronchoalveolar lavage (BAL) cells grown in the absence or presence of lipopolysaccharide (LPS) $\left(2 \mu \mathrm{g} \cdot \mathrm{mL}^{-1}\right)$. cDNA was obtained by reverse transcriptase. M: molecular weight marker; lane 1: PBMCs from a control subjects; lane 2: PBMCs from a PAP patient; lane 3: BAL cells from a control subjects; lane 4: BAL cells from a PAP patients. change in the coding for amino acids. This change at the genomic level appears to be a nonrelevant functional polymorphism.

PAP may be caused by the lack of GM-CSF protein. A recent observation indicates absence of the protein release while the GM-CSF gene expression was normal in one adult patient with PAP [16]. TCHOU-Wong et al. [16] suggest an inhibitory effect of IL-10 on GM-CSF secretion by altering translation or protein processing. However, changes in the structure of the GM-CSF molecule which may impair GM-CSF function have not been excluded. The current authors have addressed this question with this study.

In three out of four patients (PAPa, PAPb, PAPd) GMCSF release failed to respond adequately to LPS as observed in the previously described patient. BAL cells were analysed from one of these three patients and diminished GM-CSF levels were also found here. Induction of GMCSF mRNA was normal in all patients and control subjects. The kinetics of GM-CSF mRNA after treatment with LPS is similar to that observed in peritoneal mouse macrophages. No abnormalities have been found on the transcriptional level in the patient described by ТсноUWONG et al. [16].

Sequence analysis revealed a point mutation in one of the patients, whose clinical presentation at the time of diagnosis was not apparently different from the other patients. This mutation represents a change from $\mathrm{T}$ to $\mathrm{C}$ at position 382 of the published GM-CSF cDNA which will result in a change in amino acid 117 from isoleucine to threonine. Repeated analyses of completely independent clones (total of 10) demonstrated both mutated and wildtype forms of gene indicating heterozygous genomic mutation. This patient displayed the lowest level of GMCSF release in response to LPS stimulation.

Since isoleucine is hydrophobic and threonine is hydrophilic the mutation may cause changes in the polarity of the protein resulting in diminished stability or impaired function. However, the relevance of the mutation concerning the development of PAP remains uncertain because this region of the GM-CSF gene is not well preserved, e.g. 
porcine GM-CSF consists of serine at this position, another hydrophilic amino acid. Low levels of GM-CSF even after stimulation were observed in two other patients, although the GM-CSF cDNA was intact. Therefore, future studies will have to analyse factors influencing translation and stability of the protein.

Of certain interest are the findings observed in the patient PAPc emphasizing the heterogeneity of PAP. The patient suffered from histologically proven PAP in association with interstitial inflammation. All analyses of GM-CSF and GM-CSF receptor $\beta$ chain including the transcriptional and protein level, and sequencing were normal in the samples suggesting a pathway for the development of PAP not involving GM-CSF or the $\beta c$ receptor.

Careful evaluation of patients with pulmonary alveolar proteinosis is necessary before a specific treatment can be applied. Diminished levels of granulocyte-macrophage colony-stimulating factor in patients with pulmonary alveolar proteinosis may justify substitution therapy and beneficial effects have been described in a case report [24]. However, causes of pulmonary alveolar proteinosis seem to be variable and optimal therapy besides whole lung lavage depends on the underlying defect.

Acknowledgements. The authors thank S. Rohweder for excellent technical assistance and A. Bastian for valuable discussion.

\section{References}

1. Prakash UB, Barham SS, Carpenter HA, Dines DE, Marsh HM. Pulmonary alveolar phospholipoproteinosis: experience with 34 cases and a review. Mayo Clin Proc 1987; 62: 499-518.

2. Wang BM, Stern EJ, Schmidt RA, Pierson DJ. Diagnosing pulmonary alveolar proteinosis: a review and an update. Chest 1997; 111: 460-466.

3. Martin RJ, Coalson JJ, Rogers RM, Horton FO, Manous LE. Pulmonary alveolar proteinosis: the diagnosis by segmental lavage. Am Rev Respir Dis 1980;1221:819-825.

4. Wright JR, Clements JA. Metabolism and turnover of lung surfactant. Am Rev Respir Dis 1987; 136: 426-444.

5. Wright JR. Clearance and recycling of pulmonary surfactant. Am J Physiol 1990; 259: L1-L12.

6. Nogee LM, deMello DE, Dehner LP, Colten HR. Brief report: deficiency of pulmonary surfactant protein $\mathrm{B}$ in congenital alveolar proteinosis. $N$ Engl J Med 1993; 328: 406-410.

7. Nogee LM, Garnier G, Dietz HC, et al. A mutation in surfactant protein $\mathrm{B}$ gene responsible for fatal neonatal respiratory disease in multiple kindreds. $J$ Clin Invest 1994; 93: 1860-1863.

8. Harris JO. Pulmonary alveolar proteinosis: abnormal in vitro function of alveolar macrophages. Chest 1979; 76: $156-159$.

9. Nugent KM, Pesanti EL. Macrophage function in pulmonary alveolar proteinosis. Am Rev Respir Dis 1983; 127: 780-781.

10. Gonzalez-Rothi RJ, Harris JO. Pulmoary alveolar proteinosis. Further evaluation of abnormal alveolar macrophage. Chest 1986; 90: 656-616.
11. Dranoff G, Crawford AD, Sadelain M, et al. Involvement of granulocyte-macrophage colony-stimulating factor in pulmonary hemeostasis. Science 1994; 264: 713-716.

12. Stanley E, Lieschke GJ, Grail D, et al. Granulocyte/macrophage colony-stimulating factor-deficient mice show no major perturbation of hematopoiesis but develop a characteristic pulmonary pathology. Proc Natl Acad Sci USA 1994; 12: 5592-5596.

13. Robb L, Drinkwater CC, Metcalf D, et al. Hematopoietic and lung abnormalities in mice with a null mutation of the common $\beta$ subunit of the receptors for granulocytemacrophage colony-stimulating factor and interleukins 3 and 5. Proc Natl Acad Sci USA 1995; 92: 9565-9569.

14. Nishinakamura R, Nakayama N, Hirabayashi $\mathrm{Y}$, et al. Mice deficient for the IL-3/GM-CSF/IL-5 beta c receptor exhibit lung pathology and impaired immune response, while beta IL-3 receptor-deficient mice are normal. Immunity 1995; 2: 211-222.

15. Dirksen U, Nishinakamura R, Groneck P, et al. Human pulmonary alveolar proteinosis associated with a defect in GM-CSF/IL-3/IL-5 receptor common $\beta$ chain expression. $J$ Clin Invest 1997; 100: 2211-2217.

16. Tchou-Wong KM, Harkin TJ, Chi C, Bodkin M, Rom WN. GM-CSF gene expression is normal but protein release is absent in a patient with pulmonary alveolar proteinosis. Am J Respir Crit Care Med 1997; 156: 1999_ 2002.

17. Huffman JA, Hull WM, Dranoff G, Mulligan RC, Whitsett JA. Pulmonary epithelial cell expression of GM-CSF corrects the alveolar proteinosis in GM-CSFdeficient mice. J Clin Invest 1996; 97: 649-655.

18. Ikegami M, Jobe AH, Huffman JA, Whitsett JA. Surfactant metabolic consequences of overexpression of GM-CSF in the epithelium of GM-CSF deficient mice. Am J Physiol 1997; 273: L709-L714.

19. Zsengeller ZK, Reed JA, Bachurski CJ, et al. Adenovirus-mediated granulocyte-macrophage colony-stimulating factor improves lung pathology of pulmonary alveolar proteinosis in granulocyte-macrophage colony-stimulating factor-deficient mice. Hum Gene Ther 1998; 9: 21012109.

20. Nishinakamura R, Wiler R, Dirksen U, et al. The pulmonary alveolar proteinosis in granulocyte-macrophage colony-stimulating factor/interleukins $3 / 5 \beta \mathrm{c}$ receptor-deficient mice is reversed by bone marrow transplantation. $J$ Exp Med 1996; 183: 2657-2662.

21. Cooke KR, Nishinakamura R, Martin TR, et al. Persistence of pulmonary pathology and abnormal lung function in IL-3/GM-CSF/IL-5 beta c receptor-deficient mice despite correction of alveolar proteinosis after BMT. Bone Marrow Transplant 1997; 20: 657-662.

22. Dirksen U, Hattenhorst U, Schneider P, et al. Defective expression of granulocyte-macrophage colony-stimulating factor/interleukin-3/interleukin-5 receptor common $\beta$ chain in children with acute myeloid leukemia associated with respiratory failure. Blood 1998; 92: 1097-1103.

23. Parker LA, Novotny DB. Recurrent alveolar proteinosis following double lung transplantation. Chest 1997; 111: 1457-1458.

24. Seymour JF, Dunn AR, Vincent JM, Presneill JJ, Pain MC. Efficacy of granulocyte-macrophage colony-stimulating factor in acquired alveolar proteinosis. $N$ Engl $J$ Med 1996; 335: 1924-1925. 